\title{
Aggregation and divergent process of As in the bay mouth of Jiaozhou
} Bay

\author{
Dongfang Yang ${ }^{1,2,3, a}$, Sixi Zhu ${ }^{1,2}$, Fengyou Wang ${ }^{1,2, b, c}$, Xiaoli Zhao ${ }^{1,2}$ and \\ Yunjie $\mathrm{Wu}^{1,2}$ \\ ${ }^{1}$ Research Center for Karst Wetland Ecology, Guizhou Minzu University, Guizhou Guiyang, \\ Guizhou Guiyang, China;
}

${ }^{2}$ College of Chemistry and Environmental Science, Guizhou Minzu University, Shanghai, 550025, China;

${ }^{3}$ North China Sea Environmental Monitoring Center, SOA, Qingdao 266033, China.

adfyang_dfyang@126.com; ${ }^{b}$ Corresponding author; 'wangfy2001@yahoo.com.cn

Keywords: As; Distribution; Aggreation process; Divergent process; Jiaozhou Bay.

\begin{abstract}
This paper analyzed the content and distribution of Arsenic (As) in bottom waters in the bay mouth of Jiaozhou Bay in May, September and October 1983. Results showed As contents ranged from $0.15-2.30 \mu \mathrm{g} \mathrm{L}^{-1}$ in bottom waters in the whole year, and were more lower than Class I for As (20.00 $\left.\mu \mathrm{g} \mathrm{L}^{-1}\right)$ in National Standard of China for Seawater Quality (GB3097-1997). Jiaozhou Bay was very slightly contaminated by As in 1983 by means of vertical water's effect. In according to the horizontal distributions of As in the bay mouth, there was a high value region in May (1.74 $\left.\mu \mathrm{g} \mathrm{L}^{-1}\right)$ in the bay mouth, while in September and October were low value regions (0.15-0.44 $\mu \mathrm{g}$ $\mathrm{L}^{-1}$ ). There were both aggreation and divergent processes of As in the bay mouth, whose preconditions were both concave submarine landform and high flow rate, and whose decisive conditions were high contents of low contents of As in surface waters, respectively.
\end{abstract}

\section{Introduction}

Arsenic compounds were a class of critical toxic substance. For instance, arsenic oxide $\left(\mathrm{As}_{2} \mathrm{O}_{3}\right)$ was one of the famous poison in ancient times. In nowadays, arsenic compounds are widely used in industries and agriculture. A large amount of As-containing waste gas, water and slag were generated and discharged to the atmosphere, soil, and waters, and were finally discharged to the ocean. As pollution in marine environment especially in coastal waters have been serious issues in many coastal countries and regions [1-3]. As pollution is harmful to the marine ecosystem, as well as human by means of food chain.

Jiaozhou Bay is a semi-closed bay located in Shandong Province, eastern China, and has been polluted by various pollutants including marine ecosystem[1-4]. Based on the investigation data on As in different seasons in 1983, the aim of this paper was to analysis the content and distribution of As in the bay, and to provide basis for the research on the existence and transfer process of As in bay waters.

\section{Materials and method}

Jiaozhou Bay $\left(35^{\circ} 55^{\prime}-36^{\circ} 18^{\prime} \mathrm{N}, 120^{\circ} 04^{\prime}-120^{\circ} 23^{\prime} \mathrm{E}\right)$ is located in the south of Shandong Peninsula, eastern China. The area and and average water depth are $460 \mathrm{~km}^{2}$ and $7 \mathrm{~m}$, respectively, yet the bay mouth is only $2.5 \mathrm{~km}$ (Fig. 1). This bay is surrounding by cities of Qingdao, Jiaozhou and Jiaonan in the east, north and south, and is connected with the Yellow Sea in the south. There are more than ten inflow rivers such as Loushan River, Licun River and Haibo River, all of which are seasonal rivers [4-5].

The investigation on As in five sampling sites (H34, H35, H36, H37 and H82) in Jiaozhou Bay waters was conducted by North China Sea Environmental Monitoring Center in May, September and October 1983 (Fig. 1). The investigation and measurement of As were follow by National 
Specification for Marine Monitoring [6].

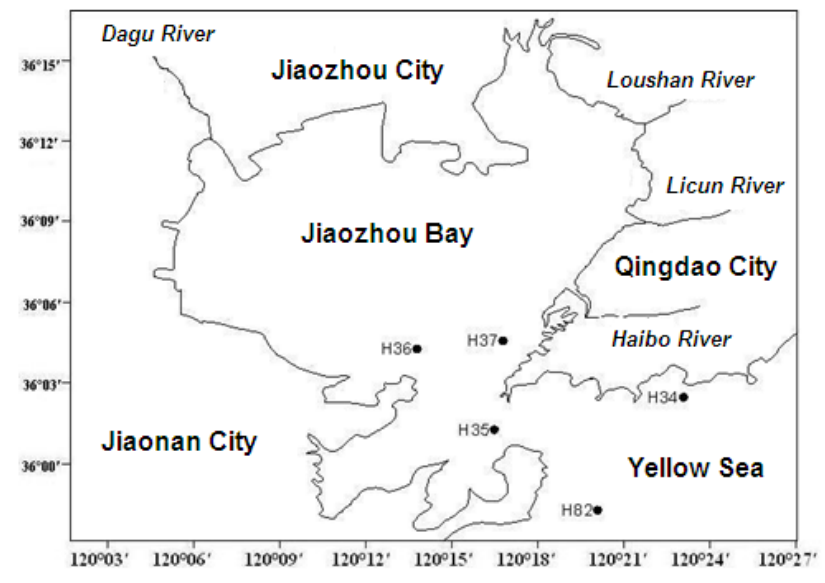

Fig.1 Geographic location and sampling sites of Jiaozhou Bay

\section{Results and discussion}

\section{Contents and pollution levels of As.}

As contents in bottom waters in the bay mouth of Jiaozhou Bay in May, September and October 1983 were ranged from 1.08-1.74 $\mu \mathrm{g} \mathrm{L}^{-1}, 0.15-2.30 \mu \mathrm{g} \mathrm{L}^{-1}$ and $0.44-1.48 \mu \mathrm{g} \mathrm{L}^{-1}$, respectively, and were ranged from $0.15-2.30 \mu \mathrm{g} \mathrm{L}^{-1}$ in the whole year. In according to the guide line of Class I for As (20.00 $\mu \mathrm{g} \mathrm{L}^{-1}$ ) in National Standard of China for Seawater Quality (GB3097-1997). The major sources of As in Jiaozhou Bay were stream flow, atmosphere deposition and marine current. From source to sink, As were originally discharged to the surface waters in the bay, and were transferred to the sea bottom through the water body finally. Hence, by means of vertical water's effect [7], As contents were still low in bottom waters in 1983.

\section{Horizontal distributions of As.}

The five sampling sites were located in the inner side (H36 and H37), middle (H35) and out side (H34 and H82) of the bay mouth. In May, there was a high value region in Site H35 in the middle of the bay mouth $\left(1.08 \mu \mathrm{g} \mathrm{L}^{-1}\right)$. The distributions of As contents were forming a series of parallel lines which were decreasing from the middle of the bay mouth to the out side of the bay mouth $(1.08 \mu \mathrm{g}$ $\mathrm{L}^{-1}$ ) (Fig. 2). In September, there was a low value region in Site H35 in the middle of the bay mouth $\left(0.15 \mu \mathrm{g} \mathrm{L}^{-1}\right)$. The distributions of As contents were forming a series of parallel lines which were increasing from the middle of the bay mouth to the out side of the bay mouth $\left(2.30 \mu \mathrm{g} \mathrm{L}{ }^{-1}\right)$ (Fig. 3). There was also a low value region in Site H35 in the middle of the bay mouth $\left(0.44 \mu \mathrm{g} \mathrm{L}^{-1}\right)$. The distributions of As contents were forming a series of parallel lines which were increasing from the middle of the bay mouth to the out side of the bay mouth $\left(1.48 \mu \mathrm{g} \mathrm{L}^{-1}\right)$ (Fig. 4). In according to the horizontal distributions, we found that there was aggregiation process of As in May, while in September and October were divergent processes.

\section{Aggregation and divergent processes of As.}

Actually, there are two narrow bay mouths namely interior bay mouth $(2.5 \mathrm{~km})$ and exterior bay mouth (3.1 km) in Jiaozhou Bay (Fig. 1). Moreover, there is a deep (40 m) water channel between the two bay mouths, in where the tidal current is very strong. For instance, the amplitude of tidal current of $\mathrm{M}_{2}$ is as high as $1 \mathrm{~m} \mathrm{~s}^{-1}$, and the instantaneous velocity of the flow in this water channel during the spring tide is $2.01 \mathrm{~m} \mathrm{~s}^{-1}$ [8]. Hence, the water exchange capacity is very strong in waters in the bay mouth [9]. The highest values of As contents in surface waters in May, September and October were $4.89 \mu \mathrm{g} \mathrm{L}^{-1}, 1.59 \mu \mathrm{g} \mathrm{L}^{-1}$ and $2.93 \mu \mathrm{g} \mathrm{L}^{-1}$, respectively. The distributions of As in bottom waters in the bay mouth were mainly determined by source strength, sedimentation and water exchange. As contents in surface waters in May were highest in the whole year, and a large amount of As was transferred to bottom waters by means of sedimentation. Hence, there was an aggregation process in May in spite of the strong water exchange capacity. In September and 
October, As contents in surface waters were relative low, and the amount of sedimentation was also small. Hence, there were divergent processes in September and October by means of strong water exchange capacity.

\section{Conclusions}

As contents in Jiaozhou Bay waters in different seasons were still very low in 1983. The distributions of As contents were forming a series of parallel lines which were decreasing from the middle of the bay mouth to the out side of the bay mouth in May, while in September and October were reverse. There was aggregation process of As in May, and divergent processes in September and October. The preconditions of both aggregation and divergent processes were concave submarine landform and high flow rate, while the decisive conditions of aggregation and divergent processes were high contents of low contents of As in surface waters, respectively.

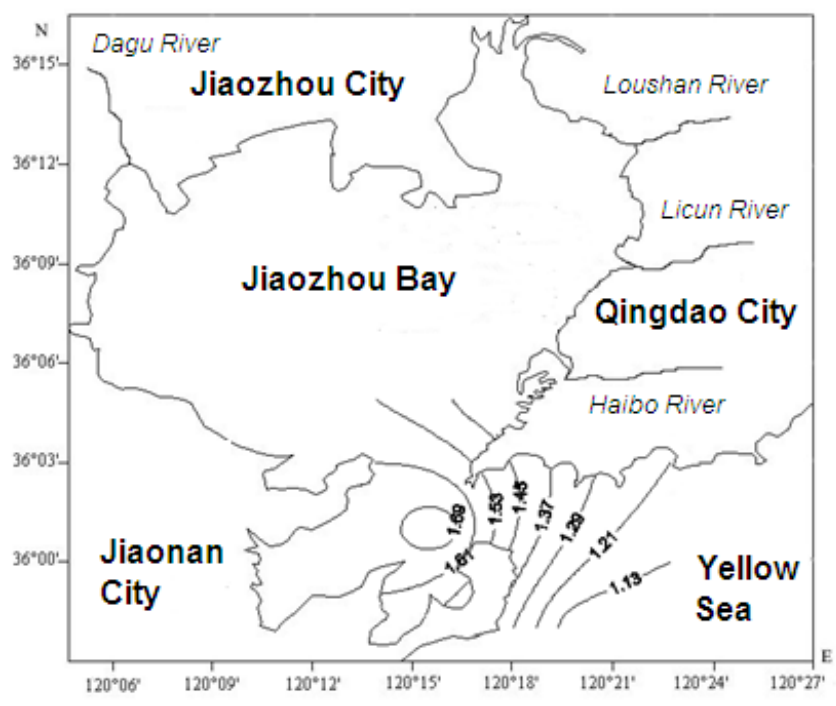

Fig. 2 Distributions of As in bottom waters in Jiaozhou Bay in May 1983/ $\mu \mathrm{g} \mathrm{L}^{-1}$

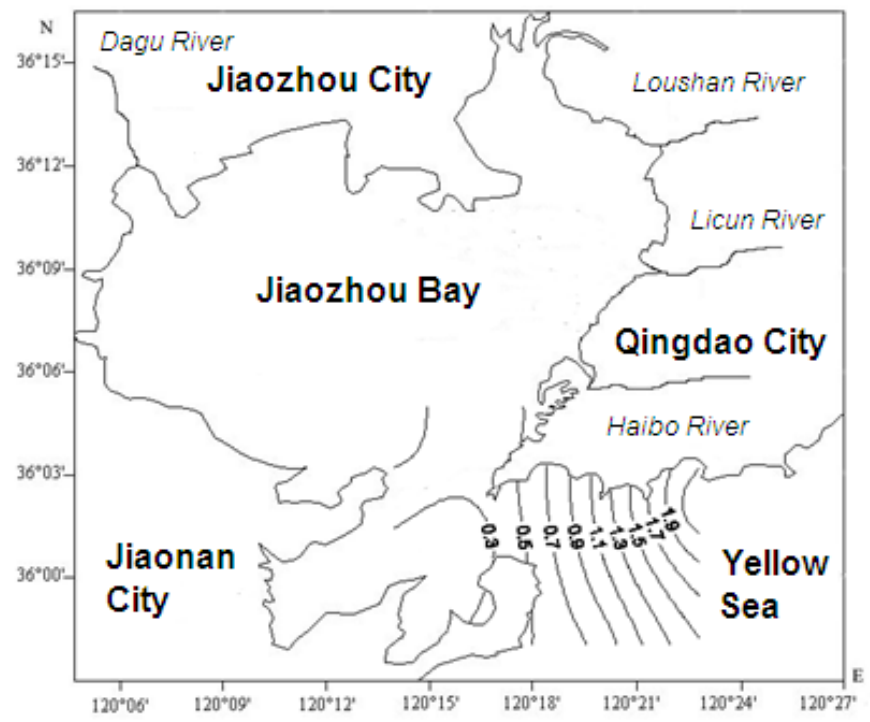

Fig. 3 Distributions of As in bottom waters in Jiaozhou Bay in September 1983/ $\mu \mathrm{g} \mathrm{L}^{-1}$ 


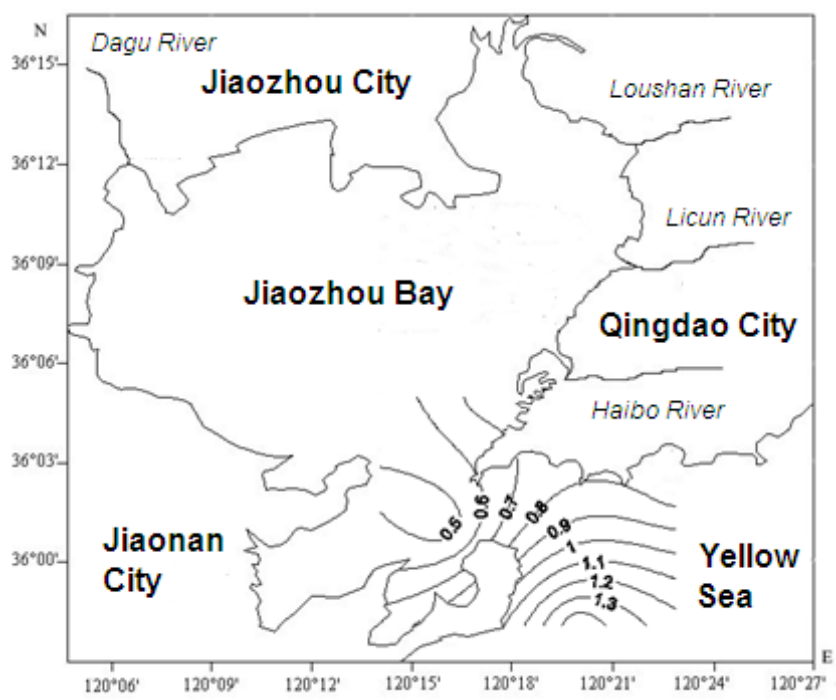

Fig. 4 Distributions of As in bottom waters in Jiaozhou Bay in October 1983/ $\mu \mathrm{g} \mathrm{L} \mathrm{L}^{-1}$

\section{Acknowledgement}

This research was sponsored by Doctoral Degree Construction Library of Guizhou Nationalities University, Education Ministry's New Century Excellent Talents Supporting Plan (NCET-12-0659), Education Ministry's New Century Excellent Talents Supporting Plan (NCET-12-0659), Project of Outstanding Technological Educators of Governor of Guizhou ([2012]71), Project of Low Carbon Technology Plan of Guiyang (2012205]), Project of Science and Technology Foundation of Guiyang (LKM[2012]05), Special Research Projects of High Level Talents of Guizhou Province (TZJF-2011-44), the China National Natural Science Foundation (31560107) and Research Projects of Guizhou Nationalities University ([2014]02), Research Projects of Guizhou Province Ministry of Education (KY [2014] 266), Research Projects of Guizhou Province Ministry of Science and Technology (LH [2014] 7376).

\section{Reference}

[1] Yang DF, Song WP, Chen ST, et al.:, Coastal Engineering, Vol. 31(2012), p. 47-55. (in Chinese)

[2] Yang DF, Zhao YH, Pu ZG, et al.: Ocean Development and Management, Vol. 31 (2014), p. 109-112. (in Chinese)

[3] Yang DF, Zhu SX, Wang FY, et al.:Meterological and Environmental Research, Vol. 5(2014), p. 24-26.

[4] Yang DF, Chen Y, Gao ZH, et al.: Chinese Journal of Oceanology and Limnology, Vol. 23 (2005), pp. 72-90.

[5] Yang DF, Wang F, Gao ZH, et al.: Marine Science, Vol. 28 (2004), p. 71-74. (in Chinese)

[6] State Ocean Administration. The specification for marine monitoring: Beijing, Ocean Precess, (1991).

[7] Yang DF, Wang FY, He HZ, et al.: Proceedings of the 2015 international symposium on computers and informatics, 2015, p. 2655-2660.

[8] Lu XG, Zhao C, Xia CS. Acta Oceanologica Sinica, Vol. 32 (2010), p. 20-30. (in Chinese)

[9] Yang DF, Miao ZQ, Xu HZ, et al.: Marine Environmental Science, Vol. 332 (2013), p. 373-380. (in Chinese) 